\title{
Pengaruh Pemberian Pakan Buatan, Pakan Alami, dan Kombinasinya terhadap Pertumbuhan, Rasio Konservasi Pakan dan Tingkat Kelulushidupan Ikan Sidat (Anguilla bicolor) \\ Effect Of Artificial Feed, Natural Feed And Combination Between Them To Growth Rate, Food Convertion Ratio And Survival Rate Of Indonesian Shortfin Eel (Anguilla bicolor)
}

\author{
Muhammad Arief, Dwi Kukuh Pertiwi dan Yudi Cahyoko \\ Fakultas Perikanan dan Kelautan Universitas Airlangga \\ Kampus C Mulyorejo - Surabaya, 60115 Telp. 031 - 5911451
}

\begin{abstract}
Indonesian shortfin eel (Anguilla bicolor) is one of kind of fish sold in the International markets especially for Japan and Korea, so this fish has the potential as an export commodity. Indonesian shortfin eel has a high nutrient content. Indonesian shortfin eel reached the size of concumption when it is weighted 120-500 grams. The purpose of this research was to know the effect of artifial feed, natural feed and combination between them to growth rate, food convertion ratio and survival rate of Indonesian shortfin eel (Anguilla bicolor). This research used experimental method and Completely Random Design method with five treatments. Each treatment was replicated four times. The result of this research showed that artificial feed, natural feed and combination between them were significantly difference $(p<0,05)$ on growth rate of body wight and food convertion ratio but not significantly difference $(p>0,05)$ on survival rate of Indonesian shortfin eel. The best growth in treatment $\mathrm{E}(1.72 \%)$, then a row followed by treatment $\mathrm{A}$ (1.51\%), B (1.29\%), D (1.25\%) and C (1.25\%). The lowest feed conversion ratio obtained in treatment E (6.73) and highest feed conversion ratio obtained in treatment $\mathrm{C}(9.91)$. Survival rate obtained was $100 \%$. Water quality of maintenance media of eel was the temperature $28-31^{\circ} \mathrm{C}, \mathrm{pH} 7-8,5$, dissolve oxygen $3,5-5,8 \mathrm{mg} / \mathrm{l}$ and ammonia 0,003 $\mathrm{mg} / \mathrm{l}$.
\end{abstract}

Keywords : Indonesian Shortfin Eel, Natural Feed, Artificial Feed, Growth Rate.

\section{Pendahuluan}

Ikan sidat (Anguilla bicolor) merupakan salah satu jenis ikan yang laku di pasar Internasional terutama Jepang dan Korea, dengan demikian ikan ini memiliki potensi sebagai komoditas eksport (Affandi, 2010). Ikan sidat mencapai ukuran konsumsi bila telah mencapai berat 120-500 gram. Waktu yang dibutuhkan untuk mencapai ukuran 120 gram adalah 8-9 bulan masa pemeliharaan (Sasongko dkk.,2007). Pertumbuhan sangat berkaitan erat dengan pakan. Pakan yang memenuhi kebutuhan gizi dapat berpengaruh terhadap kecepatan pertumbuhan. Ketersediaan pakan alami memiliki peran penting dalam budidaya ikan terutama pada stadia benih. Pada budidaya intensif pengadaan pakan buatan sangat diperlukan. Pakan buatan juga dapat melengkapi penyediaan nutrisi yang tidak terdapat dalam pakan alami (Afrianto dan Liviawaty, 2005).

Formulasi pakan buatan terus dilakukan dengan berbagai manipulasi guna meningkatkan dan memperbaiki kualitas pakan buatan. Pakan buatan adalah pakan yang dibuat dari berbagai macam bahan baku hewani dan nabati dengan memperhatikan kandungan gizi, sifat dan ukuran ikan yang akan mengkonsumsi pakan tersebut dengan cara dibuat oleh manusia dengan bantuan peralatan pakan (Gusrina, 2008). Pemberian pakan yang sesuai dengan kebutuhan selain dapat menjamin kehidupan ikan juga dapat mempercepat pertumbuhannya (Djajasewaka, 1985). Penelitian ini ingin mengkaji pengaruh pemberian pakan buatan, pakan alami, dan kombinasinya terhadap pertumbuhan, rasio konversi pakan dan tingkat kelulushidupan ikan sidat (Anguilla bicolor).

\section{Tujuan}

Mengetahui pengaruh pemberian pakan buatan, pakan alami, dan kombinasinya terhadap pertumbuhan, rasio konversi pakan dan tingkat kelulushidupan ikan sidat (Anguilla bicolor).

\section{Manfaat}

Penelitian ini diharapkan dapat memberikan informasi mengenai pemberian pakan buatan, pakan alami, dan kombinasinya yang memberikan hasil maksimal terhadap pertumbuhan, rasio konversi pakan, dan tingkat kelulushidupan ikan sidat (Anguilla bicolor).

\section{Metodologi}

Penelitian ini dilaksanakan di Laboratorium Budidaya Perikanan dan Hatchery Fakultas Teknik dan Ilmu Kelautan Universitas Hang Tuah Surabaya pada 18 November - 30 Desember 2010. Alat-alat yang digunakan dalam penelitian ini adalah 20 buah akuarium berukuran $50 \times 25 \times 30 \mathrm{~cm}^{3}$ dengan kapasitas 
volume 37,5 liter, selang aerasi, batu aerasi, termometer, ammonia test kit, DO meter, penggaris, timbangan, seser, dan shelter. Bahan penelitian yang digunakan dalam penelitian ini adalah elver sidat yang berukuran panjang tubuh rata-rata $11 \mathrm{~cm}$ dengan berat tubuh rata-rata 3 gram sebanyak 120 ekor dan didatangkan dari Dempon Udang Galah Lamongan. Pakan yang digunakan dalam penelitian ini adalah pakan alami berupa cacing sutera (T.tubifex) dan pakan buatan berupa pakan tenggelam berbentuk pasta. Metode penelitian yang digunakan dalam penelitian ini adalah metode eksperimental dengan menggunakan Rancangan Acak Lengkap (RAL). Data hasil penelitian dianalisis dengan analisis ragam (ANOVA) untuk mengetahui pengaruh perlakuan. Apabila ada pengaruh perlakuan dilanjutkan dengan Uji Jarak Berganda Duncan (Kusriningrum, 2008). Penelitian terdiri dari lima perlakuan dan empat ulangan. Perlakuan yang digunakan dalam penelitian ini adalah : A) pemberian pakan butan (pasta) $100 \%$, B) pemberian pakan buatan (pasta) $75 \%$ dan $25 \%$ pakan alami (T.tubifex),
C) pemberian pakan buatan (pasta) 50\% dan pakan almai (T.tubifex) 50\%, D) pemberian pakan buatan (pasta) 25\% dan pakan alami (T.tubifex) $75 \%$ dan E) pemberian pakan alami (T.tubifex) 100\%. Pakan perlakuan A, B, C, D dan E diberikan pada ikan sidat. Pakan diberikan dua kali sehari sebanyak 5\% dari keseluruhan berat tubuh. Ikan uji pagi hari diberi ransum sebanyak $40 \%$ dan sore hari sebanyak $60 \%$. Penyifonan dilakukan setiap hari dan penggantian air $100 \%$ dilakukan setiap minggu untuk menjaga kualitas air tetap baik. Pengukuran berat tubuh, panjang tubuh ikan dan penyesuaian jumlah pakan dilakukan setiap tujuh hari sekali guna penghitungan laju pertumbuhan harian dan panjang pertumbuhan mutlak. Selama penelitian ikan yang mati dicatat jumlahnya dan ditimbang beratnya guna penghitungan tingkat kelulushidupan. Pakan yang dikonsumsi ikan sidat dicatat setiap hari guna penghitungan rasio konversi pakan. Komposisi nutrisi pakan berdasarkan bahan kering 100\% tertera pada Tabel 1 .

Tabel 1. Komposisi nutrisi pakan berdasarkan bahan kering (100\%)

\begin{tabular}{|c|c|c|c|c|c|c|}
\hline \multirow[b]{2}{*}{ No. } & \multirow[b]{2}{*}{ Bahan kering } & \multicolumn{5}{|c|}{ Perlakuan } \\
\hline & & $\begin{array}{c}\text { A } \\
\text { PB } 100 \%\end{array}$ & $\begin{array}{c}\text { B } \\
\text { PB } 75 \% \\
\text { dan } \\
\text { PA } 25 \%\end{array}$ & $\begin{array}{c}\text { C } \\
\text { PB 50\% } \\
\text { dan } \\
\text { PA } 50 \%\end{array}$ & $\begin{array}{c}\text { D } \\
\text { PB } 25 \% \\
\text { dan } \\
\text { PA } 75 \%\end{array}$ & $\begin{array}{c}E^{*} \\
\text { PA } 100 \%\end{array}$ \\
\hline 1. & $\mathrm{Abu}(\%)$ & 11,8630 & 9,9237 & 7,9845 & 6,0452 & 4,106 \\
\hline 2. & Protein Kasar (\%) & 42,3277 & 44,8025 & 47,2773 & 49,7522 & 52,227 \\
\hline 3. & Lemak Kasar (\%) & 11,5621 & 18,3666 & 25,1710 & 31,9755 & 38,780 \\
\hline 4. & Serat Kasar (\%) & 5,2559 & 4,6729 & 4,6729 & 3,5070 & 2,924 \\
\hline 5. & $\operatorname{BETN}(\%) * *$ & 28,9913 & 22,2342 & 15,4771 & 8,7201 & 1,963 \\
\hline 6. & $\mathrm{DE}(\mathrm{kkal} / \mathrm{kg}) * * *$ & 4079,2031 & 4391,5046 & 4703,798 & 5016,1095 & 5328,41 \\
\hline 7. & $\mathrm{GE}(\mathrm{kkal} / \mathrm{kg}) * * * *$ & 4568,8179 & 5047,1003 & 5525,3736 & 6003,6656 & 6481,948 \\
\hline 8. & $\mathrm{C} / \mathrm{P}(\mathrm{kkal} / \mathrm{gr}) * * * * *$ & 9,6371 & 9,8019 & 9,9493 & 10,0821 & 10,2024 \\
\hline 9. & Jumlah pakan (gr) & 100 & 100 & 100 & 100 & 100 \\
\hline
\end{tabular}

Keterangan:

$\mathrm{PB}=$ pakan buatan (pasta); $\mathrm{PA}=$ pakan alami (T.tubifex)

*Sumber : Unit Layanan Pemeriksaan Laboratoris, Konsultasi dan Pelatihan Fakultas Kedokteran Hewan Universitas Airlangga Surabaya (2010)

$* *$ BETN $=$ Bahan Ekstrak Tanpa Nitrogen

$* * * \mathrm{DE}=$ Energi Dapat Dicerna, dimana 1 gr protein $=4 \mathrm{kkal} \mathrm{DE}, 1$ gr karbohidrat $=5 \mathrm{kkal} \mathrm{DE}, 1$ gr lemak $=8,1 \mathrm{DE}$ (NRC, 1993)

$* * * * \mathrm{GE}=$ Energi Total, dimana 1 gr protein $=5,5 \mathrm{kkal} \mathrm{GE}, 1$ gr lemak = 9,1 kkal GE, 1 gr karbohidrat = 4,1 kkal GE (Jauncey and Ross, 1982)

$* * * * * \mathrm{C} / \mathrm{P}=$ imbangan protein energi, $\mathrm{C} / \mathrm{P}=\mathrm{DE} /$ protein 
Penghitungan laju pertumbuhan harian menggunakan rumus yang dikemukakan oleh Huismann (1976). Penghitungan laju pertumbuhan mutlak menggunakan rumus yang dikemukakan oleh Effendie (2002). Penghitungan rasio konversi pakan menggunakan rumus yang dikemukakan oleh Tacon (1987) dan penghitungan tingkat kelulushidupan menggunakan rumus yang dikemukakan oleh NRC (1993).

\section{Hasil dan Pembahasan}

Hasil uji statistik menunjukkan bahwa perlakuan pemberian pakan bentuk pasta, T.tubifex, dan kombinasinya menghasilkan laju pertumbuhan ikan sidat yang berbeda nyata $(p<0,05)$. Laju pertumbuhan harian tertinggi didapat pada perlakuan $\mathrm{E}(1,72 \%)$ yang tidak berbeda nyata dengan perlakuan $\mathrm{A}(1,52 \%)$. Laju pertumbuhan harian terendah didapat pada perlakuan $\mathrm{C}(1,25 \%)$ yang tidak berbeda nyata dengan perlakuan $\mathrm{D}(1,25 \%), \mathrm{B}(1,29 \%)$ dan $\mathrm{A}(1,42 \%)$. Tabel laju pertumbuhan harian tertera pada Tabel 2.

Tabel 2. Laju pertumbuhan harian rata-rata (\%) ikan sidat (A.bicolor) pada setiap perlakuan selama penelitian 42 hari

\begin{tabular}{ccc}
\hline Perlakuan & LPH $(\%) \pm \mathrm{SD}$ & Transformasi $\sqrt{\mathrm{y}} \pm \mathrm{SD}$ \\
\hline A & $1,51 \pm 0,18$ & $1,42^{\mathrm{ab}} \pm 0,07$ \\
B & $1,29 \pm 0,03$ & $1,34^{\mathrm{b}} \pm 0,01$ \\
C & $1,25 \pm 0,40$ & $1,32^{\mathrm{b}} \pm 0,17$ \\
D & $1,25 \pm 0,16$ & $1,32^{\mathrm{b}} \pm 0,07$ \\
E & $1,72 \pm 0,06$ & $1,49^{\mathrm{a}} \pm 0,04$ \\
\hline
\end{tabular}

Keterangan:

$\mathrm{A}=100 \%$ Pasta; $\mathrm{B}=75 \%$ Pasta dan 25\% T.tubifex; $\mathrm{C}=$ $50 \%$ Pasta dan 50\% T.tubifex; D = 25\% Pasta dan 75\% T.tubifex $; \mathrm{E}=100 \%$ T.tubifex $; \mathrm{LPH}=$ Laju Pertumbuhan Harian; $\mathrm{SD}=$ standar deviasi

Superskrip yang berbeda pada kolom yang sama menunjukkan terdapat perbedaan $(\mathrm{P}<0,05)$

Superskrip yang sama pada kolom yang sama menunjukkan tidak terdapat perbedaan $(\mathrm{P}>0,05)$

Uji statistik menunjukkan bahwa perlakuan pemberian pakan bentuk pasta, T.tubifex, dan kombinasinya menghasilkan pertumbuhan panjang mutlak yang tidak berbeda nyata $(p>0,05)$ sehingga tidak dilanjutkan dengan Uji Jarak Berganda Duncan. Data rata-rata pertumbuhan panjang mutlak terdapat pada Tabel 3.
Tabel 3. Data rata-rata pertumbuhan panjang mutlak ikan sidat selama penelitian 42 hari

\begin{tabular}{cc}
\hline Perlakuan & Pertambahan panjang $(\mathrm{cm}) \pm \mathrm{SD}$ \\
\hline A & $14,40^{\mathrm{a}} \pm 1,74$ \\
B & $11,35^{\mathrm{a}} \pm 2,05$ \\
C & $11,10^{\mathrm{a}} \pm 4,30$ \\
D & $15,02^{\mathrm{a}} \pm 1,62$ \\
E & $15,00^{\mathrm{a}} \pm 4,08$ \\
\hline
\end{tabular}

Keterangan:

$\mathrm{A}=100 \%$ Pasta $; \mathrm{B}=75 \%$ Pasta dan $25 \%$ T.tubifex $; \mathrm{C}=$ $50 \%$ Pasta dan 50\% T.tubifex; D = 25\% Pasta dan 75\% T.tubifex $; \mathrm{E}=100 \%$ T.tubifex $; \mathrm{LPH}=$ Laju Pertumbuhan Harian; $\mathrm{SD}=$ standar deviasi

Superskrip yang berbeda pada kolom yang sama menunjukkan terdapat perbedaan $(\mathrm{P}<0,05)$

Superskrip yang sama pada kolom yang sama menunjukkan tidak terdapat perbedaan $(\mathrm{P}>0,05)$

Hasil uji statistik menunjukkan bahwa perlakuan pemberian pakan bentuk pasta, T.tubifex, dan kombinasinya menghasilkan rasio konversi pakan yang berbeda nyata $(\mathrm{p}<0,05)$. Rasio konversi pakan terbaik pada perlakuan $\mathrm{E}(6,73)$, dibandingkan dengan perlakuan $\mathrm{C}(9,91), \mathrm{B}(9,62), \mathrm{D}(8,85)$ dan $\mathrm{A}(8,61)$. Data rata-rata rasio konversi pakan terdapat pada Tabel 4.

Tabel 4. Data rata-rata rasio konversi pakan ikan sidat selama penelitian 42 hari

\begin{tabular}{cc}
\hline Perlakuan & FCR \pm SD \\
\hline A & $8,61^{\mathrm{a}} \pm 1,32$ \\
B & $9,62^{\mathrm{a}} \pm 1,06$ \\
C & $9,91^{\mathrm{a}} \pm 1,86$ \\
D & $8,85^{\mathrm{a}} \pm 0,73$ \\
E & $6,73^{\mathrm{b}} \pm 0,56$ \\
\hline
\end{tabular}

Keterangan :

$\mathrm{A}=100 \%$ Pasta; $\mathrm{B}=75 \%$ Pasta dan $25 \%$ T.tubifex; $\mathrm{C}=$ $50 \%$ Pasta dan $50 \%$ T.tubifex; $\mathrm{D}=25 \%$ Pasta dan $75 \%$ T.tubifex $; \mathrm{E}=100 \%$ T.tubifex $; \mathrm{LPH}=$ Laju Pertumbuhan Harian; SD = standar deviasi

Superskrip yang berbeda pada kolom yang sama menunjukkan terdapat perbedaan $(\mathrm{P}<0,05)$

Superskrip yang sama pada kolom yang sama menunjukkan tidak terdapat perbedaan $(\mathrm{P}>0,05)$

Hasil uji statistik menunjukkan bahwa perlakuan pemberian pakan bentuk pasta, T.tubifex, dan kombinasinya menghasilkan tingkat kelulushidupan yang tidak berbeda nyata $(p>0,05)$ sehingga tidak dilanjutkan uji jarak berganda 
Duncan. Data rata-rata tingkat kelulushidupan ikan sidat terdapat pada Tabel 5 dan data nilai kisaran kualitas air terdapat pada Tabel 6.

Tabel 5. Data rata-rata tingkat kelulushidupan ikan sidat selama penelitian 42 hari

\begin{tabular}{crr}
\hline Perlakuan & SR $(\%) \pm$ SD & Transformasi \pm SD \\
\hline A & $100 \pm 0,00$ & $88,82^{\mathrm{a}} \pm 0,00$ \\
B & $100 \pm 0,00$ & $88,82^{\mathrm{a}} \pm 0,00$ \\
C & $100 \pm 0,00$ & $88,82^{\mathrm{a}} \pm 0,00$ \\
D & $100 \pm 0,00$ & $88,82^{\mathrm{a}} \pm 0,00$ \\
E & $100 \pm 0,00$ & $88,82^{\mathrm{a}} \pm 0,00$ \\
\hline
\end{tabular}

Keterangan :

$\mathrm{A}=100 \%$ Pasta; $\mathrm{B}=75 \%$ Pasta dan $25 \%$ T.tubifex $; \mathrm{C}=$ $50 \%$ Pasta dan 50\% T.tubifex; D = 25\% Pasta dan 75\% T.tubifex $; \mathrm{E}=100 \%$ T.tubifex $; \mathrm{LPH}=$ Laju Pertumbuhan Harian; $\mathrm{SD}=$ standar deviasi

Superskrip yang sama pada kolom yang sama menunjukkan tidak terdapat perbedaan $(\mathrm{P}>0,05)$

Tabel 6. Nilai kisaran kualitas air media pemeliharaan ikan sidat selama 42 hari

\begin{tabular}{cc}
\hline Perlakuan & FCR \pm SD \\
\hline Suhu $\left({ }^{\circ} \mathrm{C}\right)$ & $28-31$ \\
$\mathrm{pH}$ & $7-8,5$ \\
$\mathrm{DO}(\mathrm{mg} / \mathrm{l})$ & $3,5-5,8$ \\
Amoniak $(\mathrm{mg} / \mathrm{l})$ & 0,003 \\
\hline
\end{tabular}

Hasil perhitungan statistik menunjukkan pemberian pakan pada masing-masing perlakuan dengan kandungan energi sebesar 4079,20 - 5328,41 $\mathrm{kkal} / \mathrm{kg}$ pakan dan protein sebesar 42,33 - 52,23\% mempengaruhi laju pertumbuhan harian ikan sidat $(\mathrm{p}<0,05)$. Laju pertumbuhan tertinggi didapat pada perlakuan $\mathrm{E}(1,72 \%)$ dengan pemberian $100 \%$ pakan alami berupa T.tubifex, dan laju pertumbuhan terendah pada perlakuan $\mathrm{C}(1,25 \%)$ dengan pemberian kombinasi antara 50\% pasta dan 50\% T.tubifex. Cacing T.tubifex mempunyai sifat hidup yang bergerombol dan hidup pada dasar perairan yang mengandung bahan organik, sehingga tepat untuk dijadikan sebagai pakan alami benih ikan sidat. T.tubifex memiliki kandungan serat kasar paling rendah diantara perlakuan lainnya yaitu 2,9\% sehingga lebih mudah dicerna oleh ikan sidat yang nantinya berpengaruh terhadap pertumbuhan, selain itu T.tubifex memiliki kandungan protein $(52,23 \%)$ dan energi $(5328,41 \mathrm{kkal} / \mathrm{kg}$ pakan) paling tinggi dibanding dengan perlakuan pakan buatan dan kombinasi.
Perlakuan kombinasi memiliki nilai energi dan protein yang lebih tinggi dibanding perlakuan pemberian pasta dan lebih kecil dibanding dengan perlakuan pemberian T.tubifex, tetapi laju pertumbuhan yang dihasilkan paling rendah. Berdasarkan pengamatan visual ikan sidat tampak tidak terlalu respon terhadap pakan berupa pasta yang dikombinasikan dengan T.tubifex. Hal ini berhubungan dengan jumlah pakan yang dikonsumsi selama perlakuan dimana jumlah pakan yang dikonsumsi pada perlakuan kombinasi lebih sedikit dibanding perlakuan pemberian pasta ataupun pada perlakuan pemberian T.tubifex. Sehingga energi dapat dicerna dalam pakan kombinasi sebesar 4391,50 $5016,11 \mathrm{kkal} / \mathrm{kg}$ DE tidak dapat dimanfaatkan secara maksimal yang menyebabkan laju pertumbuhan relatif rendah.

Pertumbuhan panjang mutlak yang diperoleh tidak terdapat perbedaan pada semua perlakuan $(p>0,05)$. Penelitian dengan pemberian pakan buatan, pakan alami dan kombinasinya relatif tidak menunjukkan pertumbuhan panjang yang berbeda diantara perlakuan tetapi terdapat perbedaan antar perlakuan dalam pertambahan berat badan. Hal ini menerangkan bahwa dalam penelitian ini energi yang berasal dari pakan yang diberikan disimpan dalam bentuk protein atau lemak sehingga menghasilkan pertumbuhan berat yang berbeda Diduga bahwa ikan sidat pada fase elver mengalami pertumbuhan panjang lebih dahulu sampai pada panjang tertentu, kemudian dilanjutkan dengan pertumbuhan berat.

Rasio konversi pakan terendah pada perlakuan $\mathrm{E}(6,7)$ dengan pemberian pakan alami (T.tubifex) 100\%. T.tubifex memiliki nilai kandungan protein paling tinggi dibandingkan dengan perlakuan lainnya, selain itu T.tubifex mudah dicerna (Afrianto dan Liviawaty, 2005). Rasio konversi pakan tertinggi pada perlakuan $\mathrm{C}(9,9)$ dengan perlakuan pakan buatan (pasta) 50\% dan pakan alami (T.tubifex) 50\%. Konsumsi pakan pada perlakuan $\mathrm{C}$ ini rendah dan pakan relatif kurang dimanfaatkan oleh ikan sidat sehingga nutrisi dalam pakan tersebut tidak dapat terserap oleh tubuh ikan sidat dan hanya terbuang melalui feses, selain itu laju pertumbuhan yang diperoleh relatif rendah.

Jumlah pakan dan kualitas pakan merupakan faktor penyebab rasio konversi pakan tinggi. Pemberian pakan yang berlebihan menyebabkan banyak sisa pakan sehingga rasio konversi pakan menjadi tinggi. Kualitas pakan yang tidak baik misalnya pakan yang mudah hancur atau 
bau pakan yang tidak merangsang akan menyebabkan pakan tidak termakan dan terbuang.

Masing-masing perlakuan menghasilkan tingkat kelulushidupan sebesar $100 \%$. Hal ini membuktikan bahwa pakan yang diberikan berupa pasta, T.tubifex dan kombinasinya yang dipelihara dengan padat penebaran 1,5gram/liter mampu memberikan energi yang dapat dimanfaatkan oleh ikan sidat untuk pemeliharaan dan aktivitas tubuh sehingga ikan dapat meneruskan hidupnya. Kualitas air dan pakan yang diberikan juga masih dapat ditoleransi dan mencukupi dalam pemeliharaan ikan sidat selama 42 hari. Tingkat kelulushidupan ikan dipengaruhi oleh manajemen budidaya yang baik antara lain padat tebar, kulitas pakan, kualitas air, parasit atau penyakit. Pakan yang mempunyai nutrisi yang baik sangat berperan dalam mempertahankan kelangsungan dan mempercepat pertumbuhan ikan.

Kualitas air merupakan salah satu faktor penting dalam pertumbuhan ikan. Kualitas air yang diukur pada penelitian ini meliputi suhu, $\mathrm{pH}$, oksigen terlarut dan ammonia yang masih memenuhi persyaratan untuk budidaya ikan sidat.

\section{Kesimpulan}

Pemberian pakan yang berbeda berupa T.tubifex, pakan bentuk pasta, dan kombinasi antara T.tubifex dan pasta memberikan pengaruh yang nyata terhadap pertumbuhan ikan sidat (Anguilla bicolor). Laju pertumbuhan harian tertinggi diperoleh pada perlakuan E (1,72\%) dan laju pertumbuhan terendah diperoleh pada perlakuan C $(1,25 \%)$.

Pemberian pakan yang berbeda berupa T.tubifex, pakan bentuk pasta, dan kombinasi antara T.tubifex dan pasta memberikan pengaruh yang nyata terhadap rasio konversi pakan ikan sidat (Anguilla bicolor). Rasio pakan terbaik diperoleh pada perlakuan $\mathrm{E}(6,73)$.

Pemberian pakan yang berbeda berupa T.tubifex, pakan bentuk pasta, dan kombinasi antara T.tubifex dan pasta tidak memberikan pengaruh yang nyata terhadap tingkat kelulushidupan ikan sidat (Anguilla bicolor).

Berdasarkan hasil penelitian, maka disarankan untuk menggunakan pakan alami berupa cacing T.tubifex atau pakan buatan bentuk pasta tanpa campuran pakan alami untuk menghasilkan laju pertumbuhan harian yang tinggi.

\section{Daftar Pustaka}

Affandi, R. 2010. Strategi Pemanfaatan Sumberdaya Ikan Sidat, Anguilla spp. di Indonesia. Fakultas Perikanan dan Ilmu Kelautan Institut Pertanian Bogor. Prosiding Seminar Riptek Kelautan Nasional.

Afrianto, E., dan E. Liviawaty. 2005. Pakan Ikan. Kanisius : Yogyakarta. Hal 9-77.

Djajasewaka, H. 1985. Pakan Ikan. CV Yasaguna : Jakarta.

Effendie, I. 2002. Biologi Perikanan. Yayasan Pustaka Nusatama. Yogyakarta. Hal 73-100.

Gusrina, 2008. Budidaya ikan. Direktorat Pembinaan Sekolah Menengah Kejuruan. Departemen Pendidikan Nasional. Hal 167-249.

Huismann, E. A. 1976. Food Convertion Efficiencies at Maintenance and Production Lever for Carp, Cyprinus carpio L. and Rainbow trout, Salmo gairdneri Richardson. Aquaculture, 9 : 259-273.

Jauncey, K and B. Ross. 1982. A Guide to Tilapia Feed and Feeding. Institute of Aquaculture. University of Stir Ling. Scotland. 70-75.

Kusriningrum, R.S. 2009. Buku Ajar Perancangan Percobaan. Dani Abadi Cetakan ke-2. Fakultas Kedokteran Hewan Universitas Airlangga. Surabaya. Hal 5-98.

National Research Council. 1993. Nutrient Requirement of Warmwater fishes. Sub Committee on Warmwater Fish Nitrition. Committee on Animal Nutrition. Board on Agriculture and Renewable Resources. National Academy Science. Washington, DC. 78p.

Tacon, A. G. J. 1987. The Nutrition and Feeding of Farmed Fish ang Shrimp, 1.The Essential Nutrients. Food and Agriculture Organization of United Nation. Brazil. $116 \mathrm{p}$.

Sasongko, Agus., J. Purwanto, S. Mu'minah dan U. Arie. 2007. Sidat. Penebar Swadaya; Jakarta. Hal 5-74. 
